\title{
Local Government Debt, Financing Platform and Fiscal Risk ${ }^{1}$
}

\author{
Wang Ying ${ }^{1}$, Pan Wenjie ${ }^{2}$ \\ ${ }^{1}$ Institute of Macroeconomy and Strategy, PICC Asset Management Co., Ltd., Shanghai, China \\ ${ }^{2}$ School of Statistics and Information, Shanghai University of International Business and Economics, Shanghai, \\ China \\ Correspondence: Pan Wenjie, School of Statistics and Information, Shanghai University of International \\ Business and Economics, Shanghai, 201620, China.
}

Received: January 8, 2019

Accepted: January 28, 2019

Online Published: January 29, 2019

doi:10.5539/ibr.v12n3p40

URL: https://doi.org/10.5539/ibr.v12n3p40

\begin{abstract}
The excessive expansion of local financing platform as a substantive medium for local government borrowing has aggravated local government financial risks, which may induce systemic financial risks. Based on the current debt situation of the central and provincial governments, this paper uses different measurement models to calculate debt balance and default risks of the financing platforms. The results show that nearly one-third of the provinces may have potential financial risks, therefore the central government and local governments should work together and keep four kinds of balances in order to prevent and defuse risks.
\end{abstract}

Keywords: local government debt, local financing platform, financial risk, economic growth

\section{Introduction}

Large-scale public debt not only threatens fiscal sustainability (Ghosh et al., 2013), but also affects financial stability (Cafiso, 2012) and ultimately is not conducive to long-term economic growth (Reinhart \& Gogoff, 2011). Different from the public debt problem at central government level of the typical market economy countries in Europe and America, Chinese government's debt problem is mainly concentrated at local government level, ${ }^{2}$ and the potential risks are more extensive and concealed.

Local government debt refers to the debt obligations that local governments should undertake, including explicit, implicit, or various forms ( $\mathrm{Wu} \& \mathrm{Li}, 2013$ ). Jiang \& $\mathrm{Hu}$ (2016) pointed out that local government debt is a broad concept, in explicit and implicit sense, and consists of two important components such as government-controlled entities and state-owned enterprise debt. Government-controlled entities refer to local government financing platforms, including different types of urban construction investment companies, urban construction development companies, and urban construction management companies. Before the local government has not obtained the autonomous issuance of creditor's rights, the local government mainly make up the fiscal gap and raise funds to construct municipal facilities through the local financing platform or the city investment company to issue the city investment bonds (Gong. et. 2011), the debt-paying funds are ultimately related to the local government's debt. As a substantive medium for local government borrowing, the platform undertakes the financing function of government investment projects and is considered to be a kind of Chinese-style innovation combining government power with market power (Research Group, 2011).

Mikesell (2002) believes that the main reason for the growth of local government debt is fiscal deficit. Gao (2011) points out that it could be partly attributed to anti-crisis operations. The deeper reason is local government investment impulse under GDP-based performance evaluation model. Research by Miao \& Fu (2015) shows that local governments' "competing for growth" is an important factor in promoting local government debt expansion. Chen \& Deng (2017) think that financial implicit decentralization has a significant positive correlation with local government debt. More researches have been focused on local financing platforms. It is believed that China's monetary credit has grown substantially since 2008 , and one of the main flows is local government financing

${ }^{1}$ This article only represents the author's point of view, and has nothing to do with PICC Asset Management Co., Ltd. and Shanghai University of International Business and Economics.

${ }^{2}$ In China, local governments refers to provinces, prefectures, counties, townships and villages. 
platforms. The argument put forward by Shi (2010) is based on the government stimulus investment plan of 4 trillion Yuan for two years. The total amount invested by local governments is 1.2-1.3 trillion Yuan. In fact, the debt financing through local financing platforms in 2009 reached more than 5 trillion Yuan. Under the incentives of loose macro-policy, only the expansion of local government financing platform gets instant results (Zhou, 2011). The rapid expansion of local financing platforms may lead to huge risks. First of all, financing platform companies would face high repayment risks since they lack primary business and sufficient fixed assets, at the same time they bear high debt ratio (Liu \& Zhang, 2010). Secondly, financial management opacity leads to information asymmetry, which makes banks' risk assessment and post-loan management of financing platform projects difficult (Shen \& Peng, 2010). Thirdly, financing platform projects are concentrated in medium and long-term projects with long construction cycle and large capital demand, so the mismatch of asset-liability maturity of "long-term loans and short-term deposits" has intensified the credit risk and liquidity risk of the banking system (Xiao et al., 2009).

Empirical researches on the debt size of local financing platform are quite limited. The measurement and calculation by Shi (2010) shows that the debt of local financing platform was 11.42471 trillion Yuan by the end of 2009. According to the data released by the National Audit Office in 2013, as of June 2013, the debt balance of financing platforms was equivalent to 7.8\% of GDP in of 2012. Liu \& Lu (2014) use the K-means clustering algorithm and BP neural network to establish an early warning model of the "risk threshold" for local financing platforms. Niu et al. (2016) uses no-arbitrage Nelosn-Siegel interest rate term structure expansion model to establish a joint model of government bond yield curve and the weekly data of urban investment bond spread during 2009-2014, and finds that urban investment bond risks affect government bond yield through safe haven effect and compensation effect. Based on 29 provinces' panel data from 2009 to 2013 and using the spatial econometric model, Wu \& Han (2017) find that when two regions are geographically adjacent, local government debt competition will be more intense. The reason for limited empirical researches is that local government debt under the current system is still a sensitive issue and difficult to define in laws and regulations (Gong et al., 2011). On the other hand, it is difficult to effectively control endogenous problems by conventional measurement methods (Huang \& Mao, 2015).

Based on the findings of the above-mentioned literatures, this paper firstly describes the overall situation of local government debt in China, then estimates the debt size of China's local financing platform with the help of gray forecasting model and evaluates the fiscal risk of provincial financing platform through KMV model. Lastly, the paper puts forward the policy recommendations to prevent and defuse risks.

\section{Basic Situation of Local Government Debt Balance}

China's local government debt is subject to quota management. In 2017, local government debt limit was 1.882 billion Yuan, and the actual debt balance was 1.647 billion Yuan. The limit in 2018 is 21 trillion Yuan, and as of December 16, the actual balance is 18 trillion Yuan. From the distribution among provincial governments, the top three provinces in terms of local government debt balance are Jiangsu (7.16\%), Shandong (6.23\%) and Zhejiang (5.96\%), all of which are economically developed coastal provinces, and which ranked second, third and fourth respectively in terms of GDP in 2017. The last three provinces are Tibet $(0.07 \%)$, Ningxia $(0.76 \%)$ and Qinghai $(0.87 \%)$, the corresponding GDP of which in 2017 ranked 31st, 29th and 30th respectively. It can be seen that the debt size of local governments is closely related to local economic strength. Local economic strength determines local fiscal capacity and debt repayment ability, which in turn strengthens the willingness to borrow, also boosts the confidence of debt purchase. 
Table 1. Local government debt balance (as of December 16, 2018)

\begin{tabular}{|c|c|c|c|c|c|}
\hline Region & $\begin{array}{l}\text { Local government bond } \\
\text { balance }(100 \text { million } \\
\text { Yuan) }\end{array}$ & $\begin{array}{l}\text { National share } \\
(\%)\end{array}$ & Region & $\begin{array}{l}\text { Local government } \\
\text { debt balance ( } 100 \\
\text { million Yuan) }\end{array}$ & $\begin{array}{l}\text { National } \\
\text { share }(\%)\end{array}$ \\
\hline National & 180018.42 & 100.00 & Henan & 6388.10 & 3.55 \\
\hline Beijing & 5701.44 & 3.17 & Hubei & 6552.85 & 3.64 \\
\hline Tianjin & 4001.75 & 2.22 & Hunan & 8595.57 & 4.77 \\
\hline Hebei & 6723.87 & 3.74 & Guangdong & 9594.56 & 5.33 \\
\hline Shanxi & 2805.36 & 1.56 & Guangxi & 5291.36 & 2.94 \\
\hline Inner Mongolia & 6269.82 & 3.48 & Hainan & 1829.59 & 1.02 \\
\hline Liaoning & 8289.62 & 4.60 & Chongqing & 4587.82 & 2.55 \\
\hline Jilin & 3562.14 & 1.98 & Sichuan & 9151.31 & 5.08 \\
\hline Heilongjiang & 3885.33 & 2.16 & Guizhou & 8738.05 & 4.85 \\
\hline Shanghai & 4965.90 & 2.76 & Yunnan & 6820.80 & 3.79 \\
\hline Jiangsu & 12894.34 & 7.16 & Shaanxi & 5603.57 & 3.11 \\
\hline Zhejiang & 10720.29 & 5.96 & Gansu & 2291.82 & 1.27 \\
\hline Anhui & 6451.63 & 3.58 & Qinghai & 1575.15 & 0.87 \\
\hline Fujian & 5957.27 & 3.31 & Ningxia & 1375.64 & 0.76 \\
\hline Jiangxi & 4361.18 & 2.42 & Xinjiang & 3683.77 & 2.05 \\
\hline Shandong & 11221.74 & 6.23 & Tibet & 126.79 & 0.07 \\
\hline
\end{tabular}

Source: Wind Database

Debt ratio is another indicator for observing the condition of local government debt. It should be noted that debt ratio is calculated by the government's debt with guarantee responsibility as the numerator, and the sum of local public budget revenue, revenue from government-controlled funds, subsidies granted by governments at higher levels and transfer payment as the denominator, or it is the debt that must be repaid by local finance. Since the financial crisis in 2008, the ratio of local government debt nationwide has been on the rise and fall. In 2010, it was $63.13 \%$. In 2014 , it reached a peak of $86.16 \%$. In 2017 , it fell back to $76.86 \%$. And in 2018 , it probably reached $80.10 \%$. Specifically, the ratio differs significantly among different provinces. The top three provincial governments in terms of debt ratio are Guizhou (179.5\%), Liaoning (160.9\%) and Inner Mongolia (136.2\%), and the last three provincial governments are Shanghai (52.5\%). ), Beijing (52.0\%) and Tibet (3.7\%), as shown in Figure 1.

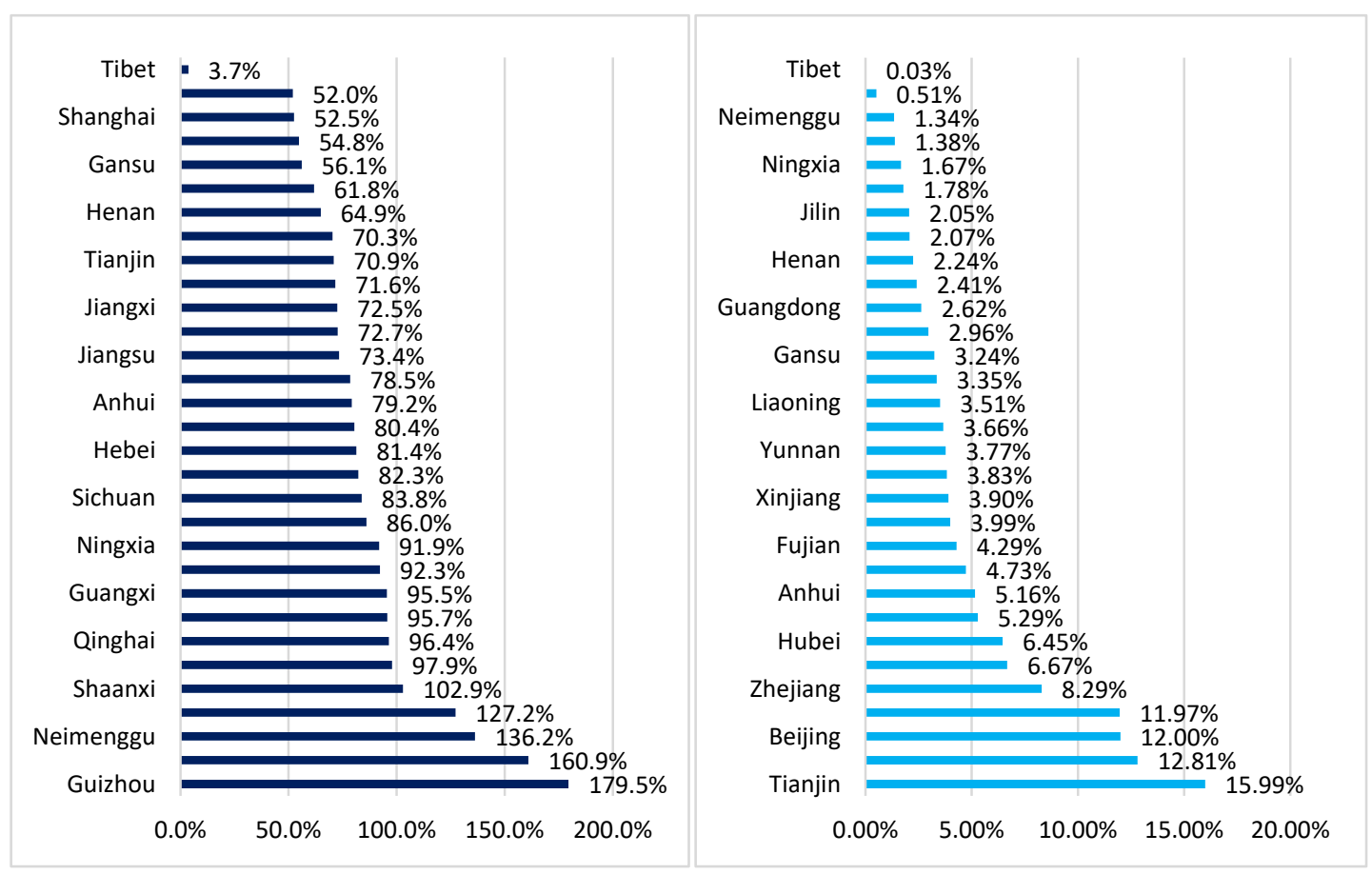

Figure 1. Debt rates of provincial governments Figure 2. Interest payment pressure of provincial government Source: Wind Database, PICC Asset Management Co., Ltd. (2018)

As for interest payment pressure indicator with annual interests of local financing platform as the numerator and the sum of local general budget expenditure and revenue from government-controlled funds in the past three years as the denominator, the interest payment pressure also differs significantly among different provinces. 
Figure 2 shows that Tianjin, Jiangsu and Beijing have the highest pressure. The possible reasons are that the debt balance of some provinces is quite high, e.g. Jiangsu, and the borrowing costs of other provinces are also high, e.g. Tianjin and Beijing.

\section{Size Calculation of Local Financing Platform Debt}

Based on the debts of financing platform companies on which the government provides full guarantees, we calculate the debt size of local financing platforms in 30 provinces (except Tibet) in China. The data is taken from Wind database and the time interval is from 2007 to 2014.

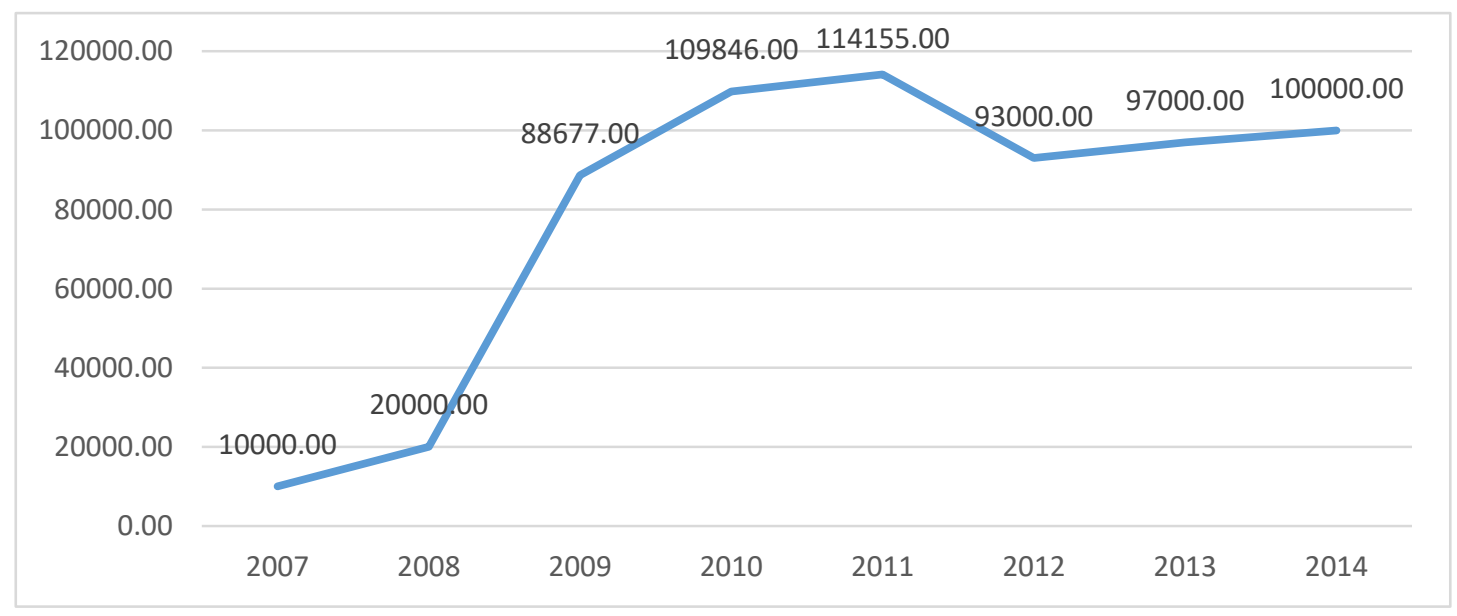

Figure 3. Debt balance of local financing platforms nationwide from 2007 to 2014

Source: Chinese Academy of Social Sciences (2015)

This paper uses gray model $(\mathrm{GM}(1,1))$ to calculate the debt balance of local financing platforms from 2015 to 2017. The advantage of the $\operatorname{GM}(1,1)$ model is that when the sample size of historical records is reduced, it can still carry out out-of-sample prediction of series. The method is often used for modeling and forecasting fiscal and tax data.

Based on the debt balance of local financing platforms nationwide from 2007 to 2014, the time series of $x^{(0)} x^{(0)}$ is established as follows:

$$
x^{(0)}=\left(x^{(0)}(1), x^{(0)}(2), \ldots, x^{(0)}(8)\right)=(10000,20000,88677,109846,114155,93000,97000,100000)
$$

To ensure the feasibility of the modeling, according to the stepwise ratio $\lambda(\mathrm{k})=x^{(0)}(k-1) / x^{(0)}(k)$, it is obtained as follows:

$$
\lambda=(\lambda(2), \lambda(3), \cdots, \lambda(8))=(0.9352,0.9295,0.9233,0.8049,0.9214,0.8827,0.8985)
$$

In this series, all stepwise ratios $\lambda(\mathrm{k})$ fall within the admissible coverage $\Theta=\left(\mathrm{e}^{-\frac{2}{n+1}}, \mathrm{e}^{\frac{2}{n+2}}\right)=(0.8007,1.2214)$. Therefore, through stepwise ratio inspection, the GM(1,1) modeling can be performed.

The raw data $x^{(0)}$ is accumulated once to generate the series 1 -AGO, i.e. $x^{(1)}$, further generate the mean series with consecutive neighbors of $x^{(1)}$

$$
z^{(1)}=\left(z^{(1)}(2), z^{(1)}(3), \cdots, z^{(1)}(8)\right)
$$

Wherein, $z^{(1)}(k)=\frac{1}{2}\left(x^{(1)}(k)+x^{(1)}(k-1)\right)$.

Then establish the gray differential equation model of $\operatorname{GM}(1,1)$ as follows: 


$$
x^{(1)}(k)+a z^{(1)}(k)=b
$$

The corresponding albinism differential equation is as follows:

$$
\frac{d x^{(1)}}{d t}+a x^{(1)}(t)=b
$$

Then construct a matrix B and a vector $Y$, in order to solve the gray differential equation (1)

$$
\begin{gathered}
\mathrm{B}=\left[\begin{array}{cccc}
-z^{(1)}(2) & -z^{(1)}(3) & \cdots & -z^{(1)}(8) \\
1 & 1 & \cdots & 1
\end{array}\right]^{T} \\
\mathrm{Y}=\left[\begin{array}{llll}
x^{(1)}(2) & x^{(1)}(3) & \cdots & x^{(1)}(8)
\end{array}\right]
\end{gathered}
$$

Let $\mathrm{u}=[a, b]^{T}$, and estimate using the least square method as follows:

$$
\hat{u}=\left[\begin{array}{l}
\hat{a} \\
\hat{b}
\end{array}\right]=\left(B^{T} B\right)^{-1} B^{T} Y
$$

Thereby, the estimation result is obtained as $\hat{a}=-0.1200, \hat{b}=15091.43$. Substitute it into the albinism differential equation (2) to obtain the following equation:

$$
\widehat{x^{(1)}}(k+1)=\left(x^{(0)}(1)-\frac{\hat{b}}{\hat{a}}\right) e^{-\hat{a} k}+\frac{\hat{b}}{\hat{a}}=135765.1 * e^{0.1200 * k}-125765.1
$$

Wherein, $\widehat{x^{(1)}}(1)=\widehat{x^{(0)}}(1)=x^{(0)}(1)=10000$.

According to equation $\widehat{x^{(0)}}(k+1)=\widehat{x^{(1)}}(k+1)-\widehat{x^{(1)}}(k)$, the predicted value series is solved as follows:

$$
\widehat{x^{(0)}}=\left(\widehat{x^{(0)}}(1), \widehat{x^{(0)}}(2), \cdots, \widehat{x^{(0)}}(11)\right)=(10000,69492.11,88677,110419.40,
$$

$$
106451.52,102626.21,98938.37,95383.05,91955.49,88651.1,85465.45)
$$

The model residual error test is performed on the prediction result. Let the residual error be $\mathrm{e}(\mathrm{k})=x^{(0)}(k)-$ $\widehat{x^{(0)}}(k)$ and calculate the relative error according to the following formula

$$
\varepsilon(\mathrm{k})=\frac{x^{(0)}(k)-\widehat{x^{(0)}}(k)}{x^{(0)}(k)}
$$

Wherein, when $\varepsilon(\mathrm{k})<0.2$, it is considered that the general requirements are met; when $\varepsilon(\mathrm{k})<0.1$, it is considered that the higher requirements are met. According to the calculation of equation (4), the average relative error $\varepsilon(\mathrm{k})$ of national data prediction is 0.1189 , which meets the general requirements. However, the financial crisis and policy effects in 2008 made the data of the year statistically abnormal, and it is found that the average relative error reaches 0.0342 after excluding the data of 2008, and the relative error and average relative error of all predictions reached higher requirements.

Using the same method, the balance of local financing platforms in 30 provinces of China is estimated. The average relative error of the model is 0.0682 , which meets the higher requirements. The specific results are as follows: 
Table 2. Estimation Results of Local Financing Platform Balances in 30 Provinces in China in 2017

\begin{tabular}{|c|c|c|c|c|c|}
\hline Region & $\begin{array}{ll}\text { Financing } & \\
\text { platform debt } \\
\text { balance } \\
\text { million Yuan) }\end{array}$ & $\begin{array}{r}\text { National share } \\
(\%)\end{array}$ & Region & $\begin{array}{l}\text { Financing platform debt } \\
\text { balance }(100 \text { million } \\
\text { Yuan) }\end{array}$ & $\begin{array}{l}\text { National } \\
(\%)\end{array}$ \\
\hline National & 85465.45 & $100.00 \%$ & Henan & 1522.17 & $1.78 \%$ \\
\hline Beijing & 55.50 & $0.06 \%$ & Hubei & 4726.98 & $5.53 \%$ \\
\hline Tianjin & 3034.90 & $3.55 \%$ & Hunan & 4075.48 & $4.77 \%$ \\
\hline Hebei & 4255.75 & $4.98 \%$ & Guangdong & 4732.38 & $5.54 \%$ \\
\hline Shanxi & 925.31 & $1.08 \%$ & Guangxi & 3178.66 & $3.72 \%$ \\
\hline \multicolumn{6}{|l|}{ Inner } \\
\hline Mongolia & 4157.57 & $4.86 \%$ & Hainan & 1195.84 & $1.40 \%$ \\
\hline Liaoning & 6421.89 & $7.51 \%$ & Chongqing & 2801.07 & $3.28 \%$ \\
\hline Jilin & 233.31 & $0.27 \%$ & Sichuan & 5410.09 & $6.33 \%$ \\
\hline Heilongjiang & 373.17 & $0.44 \%$ & Guizhou & 4329.63 & $5.07 \%$ \\
\hline Shanghai & 713.13 & $0.83 \%$ & Yunnan & 2472.01 & $2.89 \%$ \\
\hline Jiangsu & 6427.85 & $7.52 \%$ & Shaanxi & 1725.81 & $2.02 \%$ \\
\hline Zhejiang & 5475.93 & $6.41 \%$ & Gansu & 1575.39 & $1.84 \%$ \\
\hline Anhui & 3932.44 & $4.60 \%$ & Qinghai & 639.70 & $0.75 \%$ \\
\hline Fujian & 130.64 & $0.15 \%$ & Ningxia & 500.04 & $0.59 \%$ \\
\hline Jiangxi & 654.56 & $0.77 \%$ & Xinjiang & 2629.22 & $3.08 \%$ \\
\hline Shandong & 7159.02 & $8.38 \%$ & & & \\
\hline
\end{tabular}

The results show that the top five provinces with the highest proportion were Shandong $(8.38 \%)$, Jiangsu (7.52\%), Liaoning (7.51\%), Zhejiang (6.41\%) and Sichuan (6.33\%), accounting for $36.15 \%$ jointly, which basically match the actual situation of local government debt balance as shown in Table 1. It indicates that Shandong, Jiangsu, Zhejiang and other provinces mainly rely on local financing platforms to issue debts. Under the strong supervision of the Ministry of Finance and other ministries to regulate local government debts and repayment in the past two years, local governments will complete all stock debt swaps on the one hand and strictly control implicit incremental debts on the other hand.

\section{Risk Assessment of Provincial-level Local Financing Platforms}

This paper attempts to use default rate as an indicator for assessing the risks of provincial-level local financing platforms, that is, the default risk assessment indicator of local financing platforms. Drawing on the ideas of Xu (2018), we use KMV model to estimate the default probability of local financing platforms.

Suppose that local governments' debt-repaying fiscal revenue is subject to the Markov Process,

$$
\mathrm{V}_{t}=f\left(Z_{t}\right)
$$

Wherein, $V_{t}$ represents the debt-repaying fiscal revenue of the local government in the t-year, and $Z_{t}$ represents relevant random variable.

Let $B_{T}$ be financing platform debt amount due, and when the debt-repaying fiscal revenue $V_{t}$ of the local government is greater than the financing platform debt amount $B_{T}$ of the current period, it is considered that the local government will be able to repay the financing platform debt, that is, no default will occur, otherwise, it will be considered that a default will occur. Therefore, the default probability of local financing platform debt can be expressed as the probability that the debt-repaying local fiscal revenue $V_{t}$ is less than financing platform debt amount $B_{T}$ due, namely:

$$
p=P\left(V_{t}<B_{T}\right)=P\left[f\left(Z_{t}\right)<B_{T}\right]=P\left[Z_{t}<f^{-1}\left(B_{T}\right)\right]
$$

It is assumed that $Z_{t}$ obeys standard normal distribution, that is, $Z_{t} \sim N(0,1)$, and the default probability of local financing platform debt can be expressed as:

$$
p=P\left[Z_{t}<f^{-1}\left(B_{T}\right)\right]=N\left[f^{-1}\left(B_{T}\right)\right]
$$

Default distance is defined as follows:

$$
\mathrm{D} D=-f^{-1}\left(B_{T}\right)
$$

Substitute it into equation (7), then:

$$
p=N\left[f^{-1}\left(B_{T}\right)\right]=N[-D \mathrm{D}]
$$

Since local governments' debt-repaying fiscal revenue satisfies the Markov Process condition, it is assumed that 
the above probability distribution obeys the geometric Brownian motion, i.e.

$$
\mathrm{d} V_{t}=\mu V_{t} d t+\sigma d \omega_{t}
$$

Wherein, $\mu$ represents the average instantaneous growth rate of debt-repaying fiscal revenue, $\sigma$ represents the fluctuation ratio of debt-repaying fiscal revenue, and $d \omega_{t}$ represents the increase of Brownian motion.

When $t=0, V_{t}=V$. When $t>0$, debt-repaying fiscal revenue can be written as:

$$
V_{t}=V \exp \left[\left(\mu-\frac{1}{2} \sigma^{2}\right) \mathrm{t}+\sigma \sqrt{t} Z_{t}\right]
$$

Since $Z_{t}$ obeys standard normal distribution, debt-repaying fiscal revenue is subject to logarithmic normal distribution and:

$$
\begin{gathered}
E\left(\ln V_{t}\right)=\ln V+\left(\mu-\frac{1}{2} \sigma^{2}\right) t \\
=\frac{1}{\mathrm{n}-1} \sum_{i=1}^{n-1} \ln \left(V * \frac{V_{i+1}}{V_{i}}\right) \\
=\ln V+\frac{1}{\mathrm{n}-1} \sum_{i=1}^{n-1} \ln \frac{V_{i+1}}{V_{i}} \\
\operatorname{Var}\left(\ln V_{t}\right)=\sigma^{2} t \quad \\
=\frac{1}{\mathrm{n}-2} \sum_{i=1}^{n-1}\left[\ln \left(V * \frac{V_{i+1}}{V_{i}}\right)-\frac{1}{\mathrm{n}-1} \sum_{i=1}^{n-1} \ln \left(V * \frac{V_{i+1}}{V_{i}}\right)\right]^{2} \\
=\frac{1}{\mathrm{n}-2} \sum_{i=1}^{n-1}\left[\ln \frac{V_{i+1}}{V_{i}}-\frac{1}{\mathrm{n}-1} \sum_{i=1}^{n-1} \ln \frac{V_{i+1}}{V_{i}}\right]^{2}
\end{gathered}
$$

Simultaneous and solve the equations (12) and (13), the expressions of parameters $\mu$ and $\sigma$ can be obtained as follows:

$$
\begin{gathered}
\mu=\left(\frac{1}{n-1} \sum_{i=1}^{n-1} \ln \frac{V_{i+1}}{V_{i}}+\frac{1}{2} \sigma^{2} t\right) / t \\
\sigma=\sqrt{\frac{1}{\mathrm{n}-2} \sum_{i=1}^{n-1}\left[\ln \frac{V_{i+1}}{V_{i}}-\frac{1}{\mathrm{n}-1} \sum_{i=1}^{n-1} \ln \frac{V_{i+1}}{V_{i}}\right]^{2}} / t
\end{gathered}
$$

Therefore, the debt default probability of local financing platforms can be calculated as follows:

$$
p=P\left(V_{t}<B_{T}\right)=P\left(\ln V_{t}<\ln B_{T}\right)=N\left(\frac{\ln B_{T}-\ln V-\mu T+\frac{1}{2} \sigma^{2} T}{\sigma \sqrt{T}}\right)
$$

In the paper, local fiscal revenue is used as local debt-repaying fiscal revenue $V_{t}$, and the time interval is 2007-2017. According to equations (14) and (15), the parameters required for the estimation of the debt default probability of the financing platform in the KMV model of each province is estimated, and the debt-repaying fiscal revenue $V$, the average instantaneous growth rate $\mu$ of debt-repaying fiscal revenue and the fluctuation ratio $\sigma$ of debt-repaying fiscal revenue are shown in Table 3: 
Table 3. Estimation parameters of KMV model for each province

\begin{tabular}{|c|c|c|c|c|c|c|c|}
\hline Province & $\begin{array}{l}\text { Debt-repayi } \\
\text { ng revenue } \\
(100 \text { million } \\
\text { Yuan) }\end{array}$ & $\begin{array}{l}\text { Average } \\
\text { instantane } \\
\text { ous } \\
\text { growth } \\
\text { rate } \mu \text { of } \\
\text { debt-repay } \\
\text { ing } \\
\text { revenue }\end{array}$ & $\begin{array}{l}\text { Fluctuatio } \\
\mathrm{n} \text { ratio } \sigma \\
\text { of } \\
\text { debt-repay } \\
\text { ing fiscal } \\
\text { revenue }\end{array}$ & Province & $\begin{array}{l}\text { Debt-repayi } \\
\text { ng revenue } \\
(100 \text { million } \\
\text { Yuan) }\end{array}$ & $\begin{array}{l}\text { Average } \\
\text { instantaneous } \\
\text { growth rate } \mu \\
\text { of debt-repaying } \\
\text { revenue }\end{array}$ & $\begin{array}{l}\text { Fluctuatio } \\
\mathrm{n} \text { ratio } \sigma \\
\text { of } \\
\text { debt-repa } \\
\text { ying } \\
\text { fiscal } \\
\text { revenue }\end{array}$ \\
\hline Beijing & 5430.79 & 0.20 & 0.14 & Heilongjiang & 3692.41 & 0.20 & 0.09 \\
\hline Tianjin & 3000.26 & 0.21 & 0.08 & Anhui & 4312.10 & 0.23 & 0.10 \\
\hline Hebei & 4811.29 & 0.21 & 0.14 & Jiangxi & 4072.91 & 0.21 & 0.08 \\
\hline Liaoning & 5647.44 & 0.21 & 0.10 & Henan & 5001.45 & 0.22 & 0.08 \\
\hline Shanghai & 6642.30 & 0.17 & 0.16 & Hubei & 5643.01 & 0.23 & 0.10 \\
\hline Jiangsu & 8650.89 & 0.21 & 0.13 & Hunan & 4815.52 & 0.16 & 0.09 \\
\hline Zhejiang & 6592.94 & 0.19 & 0.18 & Chongqing & 2880.56 & 0.17 & 0.15 \\
\hline Fujian & 3603.42 & 0.21 & 0.08 & Sichuan & 5512.19 & 0.15 & 0.09 \\
\hline Shandong & 6834.18 & 0.20 & 0.11 & Guizhou & 4168.53 & 0.18 & 0.16 \\
\hline Guangdong & 12140.93 & 0.20 & 0.13 & Yunnan & 4082.56 & 0.24 & 0.08 \\
\hline Guangxi & 2994.84 & 0.20 & 0.14 & Shaanxi & 3432.57 & 0.21 & 0.16 \\
\hline Hainan & 982.35 & 0.22 & 0.11 & Gansu & 1803.89 & 0.21 & 0.12 \\
\hline Shanxi & 2190.78 & 0.18 & 0.08 & Qinghai & 1290.61 & 0.25 & 0.13 \\
\hline Inner Mongolia & 3254.50 & 0.25 & 0.09 & Ningxia & 998.68 & 0.19 & 0.12 \\
\hline Jilin & 2396.05 & 0.20 & 0.08 & Xinjiang & 3321.53 & 0.25 & 0.10 \\
\hline
\end{tabular}

Substituting the parameters into equation (16), we estimate the debt default probability of the local financing platform in each province in 2017. The results are as follows:

Table 4. Debt default probability of the financing platform in each province in 2017

\begin{tabular}{crcrrr}
\hline Province & $\begin{array}{c}\text { Financing platform } \\
\text { default probability } \\
(\%)\end{array}$ & Province & $\begin{array}{c}\text { Financing platform } \\
\text { default probability } \\
(\%)\end{array}$ & Province & $\begin{array}{c}\text { Financing platform } \\
\text { default probability } \\
(\%)\end{array}$ \\
\hline Beijing & & 0 & Guangxi & 3.31 & Hunan \\
Tianjin & 0 & Hainan & 9.54 & Chongqing & 0 \\
Hebei & 0.07 & Shanxi & 0 & Sichuan & 1.89 \\
Liaoning & 2.11 & Inner Mongolia & 7.80 & Guizhou & 0.06 \\
Shanghai & 0 & Jilin & 0 & Yunnan & 10.09 \\
Jiangsu & 0 & Heilongjiang & 0 & Shaanxi & 0 \\
Zhejiang & 0.35 & Anhui & 0 & Gansu & 0 \\
Fujian & 0 & Jiangxi & 0 & Qinghai & 0.01 \\
Shandong & 0.63 & Henan & 0 & Ningxia & 0 \\
Guangdong & 0 & Hubei & 0 & Xinjiang & 0 \\
\hline
\end{tabular}

According to the results, the default probability of financing platforms in 11 provinces is greater than 0 , and the top five provinces are Guizhou, Hainan, Inner Mongolia, Guangxi and Liaoning. Referring to Moody's criteria for judging bond default rate, $0.04 \%$ is adopted as the minimum default standard, it is about one third of the 30 provinces going beyond the minimum default warning line.

\section{Basic Conclusion}

The Chinese government has regarded the prevention of systemic financial risks as the top priority in the three key battles. Both the theoretical researches and operational practices prove that local fiscal risks will be transmitted to local banking system and then spread to "shadow banks", resulting in systemic financial risks that will spread to the society and eventually be converted into social risks.

The paper shows that firstly local government debt is mainly concentrated in local financing platforms, especially the local investment companies. With the transformation of the local financing platforms into real market players, the scale of local government debt will be gradually controlled. Secondly, with the decline of economic growth and increase of fiscal gap, some local governments have great pressure on debt repayment, and the fiscal risks have been gradually exposed. In order to prevent and resolve fiscal risks, we suggest the government should focus on the following four balance issues.

First of all, do a good balance between the supply and demand side of local government debt. The demand side manages local government debt in a quantitative manner, taking into account indicators such as debt ratio, newly-increased debt ratio, debt service ratio and guarantee debt ratio. The follow-up focus should be put on newly-increased debt ratio and guarantee debt ratio. For example, according to local economic development and fiscal strength, the ratio of newly-increased debt to the fiscal revenue increase of the year should not exceed 
10\%-20\%. The supply side mainly controls the behavior and scale of commercial bank loans. For example, the balance of municipal project loans issued by a commercial bank shall not be higher than a given proportion of the bank's net assets; if a local government loan project lacks sufficient cash flow, no bank is allowed to provide loans to the project, even though third-party guarantee is implemented.

Secondly, do a good balance between the overall security and local risks of local government debt. As a whole, local government debt risks are currently safe and controllable, but local risks cannot be accurately assessed. One important reason is that the transparency is quite limited. Therefore, it is necessary to establish a local debt reporting system and report it to the central government step by step, and the Ministry of Finance should conduct economic analysis on a quarterly or monthly basis to judge potential risks better. At the same time, a local debt disclosure system should be established. Local governments should publish higher-quality fiscal data on its own government networks, including major loan projects, major bond projects, annual newly-increased debts and debt maturity to protect the public's right to know and accountability power.

Thirdly, do a good balance between local debt management and treasury cash management. The former is a financing act to solve the medium and long-term fiscal deficit, while the latter focuses on short-term fiscal treasury investment and financing activities. Through accelerating the reform of local treasury cash management and operating fiscal cash assets and cash flow flexibly, the local governments can't adjust and hedge their debts effectively. At present, treasury cash management is mostly time deposits with a minimum term of three months, and county-level governments should entrust the higher-level governments to operate, which makes a large amount of unused fiscal funds at various administrative levels stay in a condition of inefficient use. Therefore, it is recommended to establish a treasury cash flow forecasting mechanism for terms ranging from one week to one year, pilot the treasury cash management operation system that appropriately authorizes cities and counties, and construct a local debt issuance mechanism that matches treasury cash management, thereby reducing the loss of sedimentary money, improving the efficiency and benefits of treasury funds, and reducing the debts of local governments.

Fourthly, do a good balance between fiscal reform and financial reform. The central government has introduced a series of rules and regulations to regulate local debt management, which all proceed from fiscal reform. Subsequently, it needs the follow-up of financial reforms. The reform will strengthen the central bank's supervision and management functions for local government debts, especially the liquidity supervision on debt maturity structure. At the same time, local governments should also change from "financiers" to "regulators", establish a local fiscal system that ensures compatible "expenditure responsibility and fiscal authority", accelerate the marketization process of local financing platforms and the construction of local bond markets, and steadily promote the replacement of local governments' stock debts.

Since October 2016, Chinese government has issued various documents to clean up local government debts. The main policy orientation is to strictly control newly-increased debts, solve stock debts, eliminate hidden debts, and promote the transformation of local financing platforms to market-orientation. We have reasons to believe that local government debt-raising will be gradually transparent and institutionalized through the strengthening of market constraints, and local debt risks will be more measurable, preventable and controllable.

\section{References}

Cafiso, G. (2012). Debt developments and fiscal adjustment in the EU. Intereconomics, 47(1), 61-72. https://doi.org/10.1007/s10272-012-0407-x

Chen, B. D., \& Deng, X. L. (2017). Fiscal Decentralization, Financial Decentralization and Local Government Debt Growth. Public Finance Research (Caizheng Yanjiu), 5, 38-53.

Gao, P. Y. (2011). Research on Chinese Government Debt Management and Asset Price Trends - A Summary of "China Government Debt Management and Asset Price Risk Seminar". Economic Research Journal (Jingji Yanjiu), 5, 154-157.

Ghosh, A. R., Kim, J. I., \& Mendoza, E. G. (2013). Fiscal Fatigue, Fiscal Space and Debt Sustainability in Advanced Economics. Economic Journal, 123(566), 4-30. https://doi.org/10.1111/ecoj.12010

Gong, Q., Wang, J., \& Jia, K. (2011). Research on Local Government Debt from the Perspective of Fiscal Decentralization: A Summary. Economic Research Journal (Jingji Yanjiu), 7, 144-155.

Gong, Q., Wang, J., \& Jia, S. (2011). Local Government Debt Research from the Perspective of Fiscal Decentralization: a review. Economic Research Journal (Jingji Yanjiu), 7, 144-156.

Huang, C. Y., \& Ma, J. (2015). Financial Situation and Local Debt Scale - new findings from the perspective of 
transfer payments. Finance \& Trade Economics (Caimao jingji), 18-31.

Jiang, Z. Y., \& Hu, Y. R. (2016). Fiscal Decentralization, Soft Budget Constraints and Local Government Debt. Financial Research (Jinrong Yanjiu), 428(2), 198-206.

Liu, H., \& Lu, Y. J. (2014). Early-warning Model and Empirical Research on Debt Risks of Local Government Financing Platforms. Economics Dynamics (Jingjixue Dongtai), 8, 63-69.

Liu, Y. H., \& Zhang J. C. (2010). Analysis of China's Local Government Financing Platform. Banker (Yinhangjia), 6, 48-52.

Miao, X. L., \& Fu, R. M. (2015). Separation of Powers and Responsibilities, the Environment of Political Achievement Profit and the Extraordinary Growth of Local Governments. Finance \& Trade Economics (Caimao Jingji), 36(4), 17-31.

Mikesell, J. L. (2002). Fiscal administration: Analysis and applications for the public sector. Cengage Learning; 10 edition (Jan.1 2017), 720 pages.

Niu, L. L., Hong, Z. W., \& Chen, G. J. (2016). The Hidden Dangers of Local Government Debt and Its Risk Transmission - based on the analysis of the yield of government bonds and the spread of city investment bonds. Economic Research Journal (Jingji Yanjiu), 11, 83-95.

Reinhart, C. M., \& Rogoff, K. S. (2011). From Financial Crash to Debt Crisis. American Economic Review, 101, 1676-1706. https://doi.org/10.1257/aer.101.5.1676

Research Group of Guangdong Institute of Fiscal Science. (2011). Local Government Investment and Financing Platform: research on risk control mechanism. Review of Economic Research (Jingji Yanjiu Cankao), 10, 28-38.

Shen, M. G., \& Peng, C. (2010). Local Financing Platform's Long View and Near Worries. China Reform (Zhongguo Gaige), 5, 38-42.

Shi, H. X. (2010). What Is the Cause of Local Debt? China Economic Times (Zhongguo Jingji Shibao), July 7 , Version 005.

Shi, Z. H. (2010). China's Local Government Debt Problems: scale measurement and policy implications. Presentation of the Institute of Chinese Educational Finance, Peking University (Beijing Daxue Zhongguo Jiaoyu Caizheng Kexue Yanjiusuo Jianbao), 41(2), 1-10.

Wu, J. P., \& Li, M. (2013). Study on Local Debt Risks in China and the Prevention - based on the investigation of central and western debts. Public Finance Research (Caizheng Yanjiu), 6, 25-30.

Wu, X. Q., \& Han, L. B. (2017). China's Local Government Debt Competition: an empirical study based on provincial spatial panel data. Finance \& Trade Economics (Caimao Jingji), 38(9), 48-62.

Xiao, G., Li, J. Y., \& Wang, Y. (2009). Take Combined Measures to Resolve the Risks of Local Government Financing Platform Loans. China Finance (Zhongguo Jinrong), 20, 40-41.

Xu, L. (2018). Local Government Debt Default Risk Measurement. Shanghai Economic Research (Shanghai Jingji Yanjiu), 1, 84-93.

Zhou, Q. R. (2011). The Entanglement of Monetary Policy and "Land Policy". China Real Estate Market (Zhongguo Dichan Shichang), 5, 88-88.

\section{Copyrights}

Copyright for this article is retained by the author(s), with first publication rights granted to the journal.

This is an open-access article distributed under the terms and conditions of the Creative Commons Attribution license (http://creativecommons.org/licenses/by/4.0/). 